\title{
PENGARUH PENAMBAHAN FERMENTASI KULIT PISANG KEPOK (Musa Paradisiaca L.) PADA PAKAN LENGKAP TERHADAP KANDUNGAN NUTRISI DAN KECERNAAN SECARA IN VITRO
}

\section{Effect of Addition Banana Peel (Musa paradisiaca L.) Fermentation in A Complete Feed on The Nutrient Contents and Digestibility by in Vitro}

\author{
Gassa Yanuar Putra ${ }^{1)}$, Herni Sudarwati ${ }^{2)}$ dan Mashudi ${ }^{2)}$ \\ ${ }^{1)}$ Mahasiswa Fakultas Peternakan Univeristas Brawijaya Jalan Veteran, Ketawanggede, Kec. Lowokwaru, Kota \\ Malang, Jawa Timur 65145 \\ ${ }^{2)}$ Dosen Fakultas Peternakan Universitas Brawijaya Jalan Veteran, Ketawanggede, Kec. Lowokwaru, Kota \\ Malang, Jawa Timur 65145 \\ Email : gassayanuar6@gmail.com
}

\begin{abstract}
ABSTRAK
Tujuan Penelitian ini adalah untuk mengetahui kandungan nutrien dan daya cerna pakan lengkap dengan penambahan fermentasi kulit pisang kepok. Bahan yang digunakan dalam penelitian ini adalah pakan lengkap dengan penambahan fermentasi kulit pisang kepok. Penelitian dilakukan dengan metode eksperimental, menggunakan Rancangan Acak Kelompok (RAK) dengan 5 perlakuan dan 3 kali ulangan. Perlakuan yang digunakan terdiri dari P0: 0\%, P1: 5\%, P2: 10\%, P3: 15\%, dan P4: 20\%. Data dianalisis menggunakan analisis ragam dengan pola RAK, diikuti oleh Uji Jarak Berganda Duncan (UJBD). Hasil penelitian menunjukkan bahwa penambahan fermentasi kulit pisang kepok berpengaruh sangat nyata $(P<0,01)$ terhadap serat kasar, protein kasar, dan lemak kasar. Sedangkan terhadap bahan organik dan abu berpengaruh nyata $(P<0,05)$. Kecernaan bahan kering dan bahan organik menunjukkan hasil berpengaruh sangat nyata $(P<0,01)$ dengan penambahan fermentasi kulit pisang kepok. Kesimpulan penelitian ini adalah pakan lengkap tanpa penambahan fermentasi kulit pisang kepok memiliki kandungan nutrisi dan kecernaan terbaik secara in vitro.
\end{abstract}

Kata kunci : Kulit pisang kepok terfermentasi, pakan lengkap, kandungan nutrisi, kecernaan bahan kering dan kecernaan bahan organik

How to Cite :

Putra, G. Y., Sudarwati, H., \& Mashudi. (2019). Pengaruh Penambahan Fermentasi Kulit Pisang Kepok (Musa Paradisiaca L.) pada Pakan Lengkap Terhadap Kandungan Nutrisi dan Kecernaan Secara In Vitro. Jurnal Nutrisi Ternak Tropis, 2 (1) 42-52
*Corresponding author :

Gassa Yanuar Putra

Email : gassayanuar6@gmail.com

Fakultas Peternakan Univeristas Brawijaya Jalan Veteran, Ketawanggede, Kec. Lowokwaru, Kota Malang, Jawa Timur 65145 


\section{ABSTRACT}

The purpose of this research were to determine of nutrient contents and digestibility complete feed with addition of banana peel fermentation. The material used in the study was complete feed with addition banana peel fermentation. The research conducted with the experimental method, using a Randomized Block Design (RBD) with 5 treatments and 3 replications. The treatments used consist of P0: 0\%, P1: 5\%, P2:10\%, P3: 15\%, and P4: 20\% of banana peel fermentation. The data were analyzed using analysis of variance, followed by Duncan Multiple Range Test (DMRT's). The results showed that addition of banana peel fermentation was highly significant $(P<0.01)$ on crude fiber, crude protein, and crude fat. The results also showed on organic matter and ash were significant $(P<0.05)$. Dry matter and organic matter digestibility showed highly significant $(P<0.01)$ with addition of banana peel fermentation. The conclusion of this research was the complete feed without addition of banana peel fermentation has the best on nutrient contents and digestibility by in vitro.

Keywords : Banana peel fermentation, complete feed, nutrient contents, dry matter and organic matter digestibilty

\section{PENDAHULUAN}

Keberhasilan sektor peternakan dipengaruhi oleh 3 aspek salah satunya adalah pakan. Pakan memiliki persentase sebesar $70 \%$ dari total biaya produksi. Pemilihan bahan pakan yang mudah didapat, dari segi harga murah, dan ketersedian secara kontinyu menjadi hal terpenting pada pakan dalam menunjang produktivitas ternak. Permasalahan pakan yang ada dipeternakan Indonesia adalah ketersediaan hijauan yang fluktuatif. Hijauan pada musim kemarau akan menjadi terbatas ketersediaannya begitu pula sebaliknya. Hal tersebut mendorong para peternak untuk memanfaatkan pakan alternatif demi memenuhi kebutuhan pakan pada ternak yang dipeliharanya. Pakan alternatif dapat diperoleh dari limbah pertanian, perkebunan maupun agroindustri.

Salah satu limbah perkebunan atau agroindustri yang bisa dimanfaatkan adalah limbah dari buah pisang. Pada tahun 2016 produksi pisang nasional sebesar 7.007.125 ton/tahun (Anonimus, 2016). Hal tersebut menandakan potensi untuk memanfaatkan limbah dari buah pisang sebagai pakan alternatif. Salah satu jenis limbah dari buah pisang yang bisa dimanfaatkan adalah limbah kulit pisang kepok. Kandungan nutrisi kulit pisang kepok antara lain lain PK
$3,63 \%$, LK 2,52\%, SK 18,71\%, Ca 7,18\%, dan P 2,06\% (Koni, 2013). Penggunaan limbah perkebunan sebagai pakan untuk ternak diperlukan strategi pengolahan dengan tujuan memperbaiki kandungan nutrisi.

Fermentasi merupakan perombakan substrat organik melalui enzim yang dihasilkan mikroorganisme untuk menghasilkan senyawa sederhana. Salah satu jenis mikroorganisme yang dapat digunakan dalam proses fermentasi adalah $\mathrm{EM}_{4}$ (effective microorganism-4). $\mathrm{EM}_{4}$ merupakan suatu kultur campuran berbagai mikroorganisme antara lain bakteri fotosintetik, bakteri asam laktat (Lactobacillus sp), actinomycetes, dan ragi yang dapat digunakan sebagai inokulum (Has, Indi, dan Pagala, 2017). Keuntungan fermentasi dengan $\mathrm{EM}_{4}$ antara lain memperbaiki kandungan nutrisi, mendegradasi serat kasar, memperbaiki rasa dan aroma pakan. Kulit pisang kepok yang difermentasi dengan menggunakan $\mathrm{EM}_{4}$ meningkatkan protein kasar sebesar 14,14\% dan menurunkan serat kasar sebesar 18,58\% (Agustono, Herviana dan Nurhajati, 2011).

Penambahan sumber karbohidrat mudah larut dalam proses fermentasi dapat meningkatkan aktivitas mikroorganisme sehingga proses fermentasi dapat berjalan optimal. Daun ubi kayu yang difermentasi 
dengan penambahan dedak mampu meningkatkan protein kasar hingga 26,34\% (Santoso dan Aryani, 2007). Keberhasilan proses fermentasi dipengaruhi oleh beberapa faktor antara lain ketersediaan substrat, dosis inokulum, jenis mikroorganisme, waktu fermentasi, $\mathrm{pH}$, dan suhu (Astuti, Sari, dan Zulkarnain, 2013). Kulit pisang terfermentasi mampu menggantikan rumput lapangan dalam pakan lengkap sampai $40 \%$ dengan kecernaan bahan kering $74,58 \%$ dan kecernaan bahan organik berkisar $72,63 \%$ (Astuti, 2015). Berdasarkan uraian tersebut penelitian ini bertujuan untuk mengetahui pengaruh penambahan fermentasi kulit pisang kepok (Musa paradisiaca L.) dalam pakan lengkap terhadap kandungan nutrisi, kecernaan bahan kering, dan kecernaan bahan organik secara in vitro.

\section{MATERI DAN METODE}

Penelitian ini dilaksanakan di Laboratorium Nutrisi dan Makanan Ternak, Fakultas Peternakan, Universitas Brawijaya Malang dengan periode penelitian dari Januari sampai Maret 2018. Materi penelitian yang digunakan adalah kulit pisang kepok merah, konsentrat, rumput gajah, daun gamal, pollard, $\mathrm{EM}_{4}$ peternakan. Kulit pisang kepok di oven $60^{\circ} \mathrm{C}$ selama 4 jam, kemudian kulit pisang difermentasi dengan penambahan pollard $10 \%$ (berdasarkan BK) dan $\mathrm{EM}_{4} 6 \%$ kemudian diinkubasi selama 1 minggu secara anaerob. Kulit pisang yang telah terfermentasi kemudian dikeringkan. Penyusunan proporsi pakan lengkap berdasarkan bahan kering pada setiap bahan pakan penyusun.

Metode yang digunakan adalah metode percobaan dengan Rancangan Acak Kelompok (RAK) 5 perlakuan dan 3 ulangan, sebagai berikut:

P0: Konsentrat 40\% + Hijauan 60\% (30\% rumput gajah dan $30 \%$ daun gamal)

P1: Konsentrat 40\% + Hijauan 60\% (30\% rumput gajah dan $30 \%$ daun gamal) + K. Pisang Terfermentasi 5\%
P2: Konsentrat 40\% + Hijauan 60\% (30\% rumput gajah dan $30 \%$ daun gamal) + K. Pisang Terfermentasi $10 \%$

P3: Konsentrat 40\% + Hijauan 60\% (30\% rumput gajah dan $30 \%$ daun gamal) + K. Pisang Terfermentasi $15 \%$

P4: Konsentrat 40\% + Hijauan 60\% (30\% rumput gajah dan $30 \%$ daun gamal) + K. Pisang Terfermentasi $20 \%$

\section{Variabel Penelitian}

Variabel penelitian yang diukur meliputi kandungan nutrisi (BK, BO, PK, SK, LK, dan Abu), kecernaan bahan kering, dan kecernaan bahan organik. Kandungan nutrisi dilakukan dengan menggunakan analisis proksimat, sedangkan kecernaan bahan kering dan kecernaan bahan organik menggunakan metode produksi gas .

\section{Analisis Data}

Data dianalisis dengan menggunakan Analisis Ragam pola RAK dengan bantuan Microsoft Excel 2010, apabila terdapat pengaruh dilanjutkan Uji Jarak Berganda Duncan (UJBD). Analisis Regresi Linear menggunakan bantuan SPSS.

\section{HASIL DAN PEMBAHASAN}

\section{Kandungan Nutrisi Kulit Pisang Kepok Sebelum dan Sesudah Difermentasi}

Kandungan nutrisi kulit pisang kepok terdapat perbedaan sebelum dan sesudah fermentasi. Hasil kandungan nutrisi kulit pisang kepok disajikan dalam Tabel 1.

Kandungan bahan kering (BK) mengalami peningkatan sebesar 4,64\%. Peningkatan bahan kering disebabkan oleh kandungan air dalam produk fermentasi lebih sedikit dibandingkan sebagian air yang keluar dari produk fermentasi (Mookolang, Wolayan, Imbar, dan Loar, 2018). Kandungan bahan organik (BO) mengalami peningkatan sebesar $4,11 \%$. Peningkatan bahan organik disebabkan oleh adanya peningkatan biomassa dari aktivitas mikroorganisme selama proses fermentasi (Suprayogi, 2010). 
Tabel 1. Kandungan Nutrisi Kulit Pisang Kepok (Musa paradisiaca L.) dan Hasil Fermentasi

\begin{tabular}{ccc}
\hline $\begin{array}{c}\text { Kandungan Nutrisi } \\
(\%)^{*}\end{array}$ & $\begin{array}{c}\text { Kulit Pisang tanpa fermentasi } \\
(\%)\end{array}$ & $\begin{array}{c}\text { Kulit Pisang Terfermentasi } \\
(\%)\end{array}$ \\
\hline BK & 14,76 & 19,40 \\
BO & 84,34 & 88,45 \\
PK & 4,52 & 5,92 \\
SK & 12,36 & 10,92 \\
LK & 15,58 & 11,62 \\
Abu & 15,66 & 11,55
\end{tabular}

Keterangan : *) Berdasarkan 100\% BK

- Hasil analisis Laboratorium Nutrisi dan Makanan Ternak, Fakultas Peternakan, Universitas Brawijaya Tahun 2018

Peningkatan protein kasar (PK) pada kulit kepok terfermentasi hanya sebesar $0,97 \%$ dan tergolong rendah. Peningkatan protein kasar yang tinggi disebabkan mikroorganisme dalam $\mathrm{EM}_{4}$ terdapat mikroorganisme yang menghasilkan enzim selulase dan protease yang mampu memecah ikatan protein. Selain itu, peningkatan protein kasar disebabkan protein sel tunggal dari mikroorganisme yang berkembang selama proses fermentasi (Has, Indi, dan Pagala, 2017). Kandungan serat kasar (SK) kulit pisang kepok terfermentasi mengalami penurunan cukup rendah sebesar 1,44\%. Mikroorganisme dalam $\mathrm{EM}_{4}$ menghasilkan enzim selulase dan ligninase yang digunakan untuk merombak selulosa dan lignin (Nuraini, Mahata, dan Djulardi, 2014).

Penurunan lemak kasar (LK) pada kulit pisang kepok terfermentasi sebesar $3,96 \%$. Penurunan kandungan lemak ini disebabkan oleh aktivitas mikroorganisme dalam merombak substrat yang ada. Hal ini sesuai dengan pendapat Manorek, Wolayan, Untu, dan Liwe (2018) bahwa meningkatnya aktivitas mikroba dalam merombak senyawa kompleks menjadi senyawa sederhana sehingga lemak kasar mudah didegradasi selama fermentasi berlangsung. Kandungan abu kulit pisang kepok terfermentasi mengalami penurunan berkisar $4,11 \%$. Penurunan kandungan abu memiliki korelasi yang positif dengan kandungan bahan organik. Korelasi kandungan abu dengan kandungan bahan organik dapat diartikan semakin sedikit kandungan bahan organik yang terdegradasi maka kandungan abu yang turun relatif kecil secara proporsional, apabila kandungan organik terdegradasi semakin besar maka kenaikan kandungan abu menjadi lebih besar secara proporsional (Styawati, Muhtarudin, dan Liman, 2014).

\section{Kandungan Nutrisi Bahan Pakan Penyusun Pakan Lengkap}

Pakan lengkap merupakan pakan yang disusun dari beberapa bahan pakan dan diformulasikan sesuai dengan kebutuhan ternak. Pakan lengkap disusun dari rumput gajah, daun gamal, konsentrat, dan kulit pisang kepok terfermentasi. Kandungan nutrisi pada bahan pakan penyusun pakan lengkap ditampilkan pada Tabel 2. pakan lengkap yang baik dari segi nutrisi mampu memenuhi kebutuhan ternak untuk produksi maupun hidup pokok.

Protein kasar (PK) pada pakan lengkap minimal $>7 \%$, kandungan protein kasar pada pakan lengkap $<7 \%$ menyebabkan aktivitas mikroba rumen dalam mendegradasi pakan menjadi terhambat akibat kurangnya pasokan nitrogen yang diperlukan mikroba untuk menunjang pertumbuhannya (Permana, Chuzaemi, Marjuki, dan Mariyono, 2014).

Kandungan serat kasar (SK) pada pakan lengkap minimal $>15 \%$. Kandungan serat kasar yang terlalu rendah pada pakan akan mempengaruhi aktivitas mikroba di dalam rumen. Serat kasar diperlukan ternak ruminansia untuk merangsang aktivitas mikroba di dalam rumen. Serat kasar yang 
terlalu tinggi akan menimbulkan masalah yaitu menurunnya konsumsi pakan dikarenakan pakan sulit didegradasi oleh mikroba rumen. Menurut Wina dan Susana (2013) menyatakan bahwa tingginya kadar lemak kasar $(>5 \%)$ dalam pakan akan menyebabkan pengaruh negatif lemak terhadap kecernaan serat kasar di dalam rumen.

\section{Kandungan Nutrisi Pakan Lengkap Dengan Penambahan Kulit Pisang Kepok Terfermentasi \\ Bahan Kering.}

Hasil analisis ragam pada Tabel 3. menunjukkan bahwa penambahan kulit pisang kepok terfermentasi memberikan hasil berpengaruh sangat nyata $(\mathrm{P}<0,01)$ terhadap kandungan bahan kering pakan lengkap. Penurunan kandungan bahan kering berkisar 0,62-1,99\%. Penurunan kandungan bahan kering disebabkan oleh rendahnya kandungan bahan kering kulit pisang kepok terfermentasi $(19,40 \%)$ jika dibandingkan dengan kandungan bahan kering pakan P0 (21,30\%). Semakin besar penambahan kulit pisang kepok terfermentasi maka semakin menurunkan perlakuan.

\section{Bahan Organik}

Hasil analisis ragam pada Tabel 3. menunjukkan bahwa penambahan kulit pisang kepok terfermentasi memberikan hasil berpengaruh nyata $(\mathrm{P}<0,05)$ terhadap kandungan bahan organik pakan lengkap. Kandungan bahan organik mengalami penurunan pada perlakuan P1 $-0,11 \%$ dan
P4 $-0,13 \%$, sedangkan pada perlakuan P2 mengalami peningkatan $+0,27 \%$ dan $\mathrm{P} 3$ $+0,19 \%$. Perbedaan kandungan bahan organik disebabkan oleh kandungan abu pada tiap perlakuan. Hal ini sesuai dengan pendapat Fariani, Astuti, Muslim, dan Abrar (2014) bahwa bahan organik berkaitan erat dengan bahan kering dan perbedaan kandungan bahan organik disebabkan oleh kandungan abu yang terkandung dalam suatu pakan.

\section{Protein Kasar}

Hasil analisis ragam pada Tabel 3 . menunjukkan bahwa penambahan kulit pisang kepok terfermentasi memberikan hasil berpengaruh sangat nyata $(\mathrm{P}<0,01)$ terhadap kandungan protein kasar pakan lengkap. Penurunan kandungan protein kasar berkisar 0,29-1,1\%. Penurunan kandungan protein kasar disebabkan oleh rendahnya kandungan protein kasar kulit pisang kepok terfermentasi $(5,92 \%)$ jika dibandingkan kandungan protein kasar P0 $(15,9 \%)$. Semakin besar penambahan kulit pisang kepok terfermentasi maka semakin menurunkan kandungan protein kasar pada tiap perlakuan.

Menurut penelitian Fitriani dan Asyari (2017) bahwa kandungan protein kasar pakan komplit dengan penambahan azolla mengalami peningkatan sebesar 9,45$10,50 \%$. Pada level penambahan azolla $25 \%$ meningkatkan kandungan protein kasar sebesar $10,50 \%$. Hal ini disebabkan oleh tingginya kandungan protein kasar pada azolla $24 \%$ serta banyaknya level yang ditambahkan.

Tabel 2. Kandungan Nutrisi Bahan Pakan Penyusun Pakan Lengkap dan Pakan Lengkap

\begin{tabular}{lccrrrr}
\multirow{2}{*}{\multicolumn{1}{c}{ Bahan Pakan }} & \multicolumn{7}{c}{ Kandungan nutrisi $(\%)^{*}$} \\
\cline { 2 - 7 } & BK & BO & \multicolumn{1}{c}{ PK } & \multicolumn{1}{c}{ SK } & \multicolumn{1}{c}{ LK } & Abu \\
\hline Rumput Gajah & 13,82 & 82,23 & 7,51 & 34,57 & 2,71 & 17,77 \\
Daun Gamal & 22,29 & 89,85 & 15,54 & 17,12 & 5,69 & 10,15 \\
Konsentrat & 88,30 & 83,53 & 16,86 & 14,03 & 3,85 & 16,47 \\
Kulit Pisang Fermentasi & 19,40 & 88,45 & 5,92 & 10,92 & 11,62 & 11,55 \\
Pakan Lengkap & 21,30 & 89,74 & 15,90 & 23,18 & 3,54 & 10,27 \\
\hline
\end{tabular}

Sumber : *) Berdasarkan 100\% BK

Hasil analisa proksimat Laboratorium Nutrisi dan Makanan Ternak, Fakultas Peternakan, Universitas Brawijaya Tahun 2018 
Tabel 3. Kandungan Nutrisi Pakan Lengkap dengan Penambahan Kulit Pisang Kepok Terfermentasi

\begin{tabular}{ccccccc}
\hline $\begin{array}{c}\text { Perl } \\
\text { akua } \\
\text { n }\end{array}$ & BK & BO & PK & SK & LK & Abu \\
\hline P0 & $21,30^{\mathrm{d}} \pm 0,06$ & $89,74^{\mathrm{ab}} \pm 0,08$ & $15,90^{\mathrm{c}} \pm 0,21$ & $23,18^{\mathrm{b}} \pm 0,81$ & $3,54^{\mathrm{a}} \pm 0,26$ & $10,27^{\mathrm{bc}} \pm 0,08$ \\
P1 & $20,62^{\mathrm{cd}} \pm 0,06$ & $89,63^{\mathrm{a}} \pm 0,17$ & $15,61^{\mathrm{bc}} \pm 0,29$ & $22,92^{\mathrm{b}} \pm 0,25$ & $4,29^{\mathrm{b}} \pm 0,10$ & $10,38^{\mathrm{c}} \pm 0,17$ \\
P2 & $20,47^{\mathrm{c}} \pm 0,05$ & $90,01^{\mathrm{c}} \pm 0,14$ & $15,21^{\mathrm{abc}} \pm 0,29$ & $22,29^{\mathrm{b}} \pm 0,62$ & $5,19^{\mathrm{c}} \pm 0,13$ & $9,99^{\mathrm{a}} \pm 0,14$ \\
P3 & $19,60^{\mathrm{b}} \pm 0,09$ & $89,93^{\mathrm{bc}} \pm 0,11$ & $14,12^{\mathrm{a}} \pm 0,57$ & $21,33^{\mathrm{ab}} \pm 0,71$ & $5,23^{\mathrm{c}} \pm 0,47$ & $10,07^{\text {ab }} \pm 0,11$ \\
P4 & $19,31^{\mathrm{a}} \pm 0,05$ & $89,61^{\mathrm{a}} \pm 0,07$ & $14,66^{\mathrm{ab}} \pm 0,57$ & $19,92^{\mathrm{a}} \pm 0,32$ & $5,45^{\mathrm{c}} \pm 0,05$ & $10,39^{\mathrm{c}} \pm 0,07$ \\
\hline
\end{tabular}

Keterangan: - superskrip yang berbeda pada kolom BO dan Abu menunjukkan berbeda nyata $(\mathrm{P}<0,05)$

- superskrip yang berbeda pada kolom BK, PK, SK dan LK menunjukkan berbeda sangat nyata $(\mathrm{P}<0,01)$

\section{Serat Kasar}

Berdasarkan hasil analisis ragam pada Tabel 3. menunjukkan bahwa penambahan kulit pisang kepok terfermentasi memberikan hasil berpengaruh sangat nyata $(\mathrm{P}<0,01)$ terhadap kandungan serat kasar pakan lengkap. Penurunan kandungan serat kasar berkisar 0,26-3,26\%. Penurunan kandungan serat kasar disebabkan oleh rendahnya kandungan serat kasar kulit pisang kepok terfermentasi $(10,92 \%)$ jika dibandingkan kandungan serat kasar P0 $(23,18 \%)$. Semakin besar penambahan kulit pisang kepok terfermentasi semakin menurunkan kandungan serat kasar pada tiap perlakuan.

\section{Lemak Kasar}

Hasil analisis ragam pada Tabel 3. menunjukkan bahwa penambahan fermentasi kulit pisang kepok memberikan hasil berpengaruh sangat nyata $(\mathrm{P}<0,01)$ terhadap kandungan lemak kasar pakan lengkap. Peningkatan kandungan lemak kasar pakan lengkap berkisar 0,93-2,25\%. Peningkatan kandungan lemak kasar pada tiap perlakuan disebabkan oleh tingginya kandungan lemak kasar kulit pisang terfermentasi $(11,62 \%)$ jika dibandingkan kandungan lemak kasar P0 (3,54\%). Menurut Wina dan Susana (2013) menyatakan bahwa tingginya kadar lemak kasar (>5\%) dalam pakan akan menyebabkan pengaruh negatif lemak terhadap kecernaan serat kasar di dalam rumen.

\section{Abu}

Berdasarkan analisis ragam pada Tabel 3. menunjukkan bahwa penambahan fermentasi kulit pisang kepok memberikan hasil berbeda nyata $(\mathrm{P}>0,05)$ terhadap kandungan abu pakan lengkap. Perubahan kandungan abu tiap perlakuan masingmasing sebesar $+0,11 \%(\mathrm{P} 1) ;-0,27 \%(\mathrm{P} 2)$; $0,20 \%$ (P3); dan $+0,12 \%$ (P4). Penurunan kandungan abu terjadi pada perlakuan $\mathrm{P} 2$ dan P3 tetapi mengalami peningkatan pada perlakuan P1 dan P4. Perbedaan kandungan abu pada tiap perlakuan berkorelasi positif dengan kandungan bahan organik pada tiap perlakuanBerdasarkan hasil penelitian Wulandari, Fathul, dan Liman (2015) bahwa kandungan abu yang baik untuk pakan ternak tidak lebih dari 15\%, hal tersebut sebagai acuan dalam pembuatan pakan ternak sehingga dapat meningkatkan pertumbuhan menjadi lebih optimal.

Kecernaan Bahan Kering dan Kecernaan Bahan Organik Pakan Lengkap dengan Penambahan Kulit Pisang Kepok Terfermentasi

Hasil analisis pengaruh penambahan kulit pisang kepok (Musa paradisiaca L.) terfermentasi dalam pakan lengkap terhadap nilai kecernaan bahan kering dan kecernaan bahan organik secara in vitro ditampilkan ke dalam Tabel 4. 
Tabel 4. Nilai KcBK dan KcBO Pakan Lengkap dengan Penambahan Kulit Pisang Kepok Terfermentasi

\begin{tabular}{ccc}
\hline \multirow{2}{*}{ Perlakuan } & \multicolumn{3}{c}{ Variabel } \\
\cline { 2 - 3 } & KcBK & KcBO \\
\hline P0 & $53,54^{\mathrm{c}} \pm 1,08$ & $60,51^{\mathrm{c}} \pm 2,39$ \\
P1 & $49,31^{\mathrm{b}} \pm 2,88$ & $58,48^{\mathrm{bc}} \pm 1,70$ \\
P2 & $47,28^{\mathrm{a}} \pm 1,62$ & $56,18^{\mathrm{abc}} \pm 2,28$ \\
P3 & $47,12^{\mathrm{a}} \pm 1,54$ & $55,65^{\mathrm{ab}} \pm 2,16$ \\
P4 & $46,18^{\mathrm{a}} \pm 1,97$ & $53,66^{\mathrm{a}} \pm 2,38$ \\
\hline
\end{tabular}

Keterangan: superskrip yang berbeda pada kolom KcBK dan KcBO menunjukkan berbeda sangat nyata $(\mathrm{P}<0,01)$

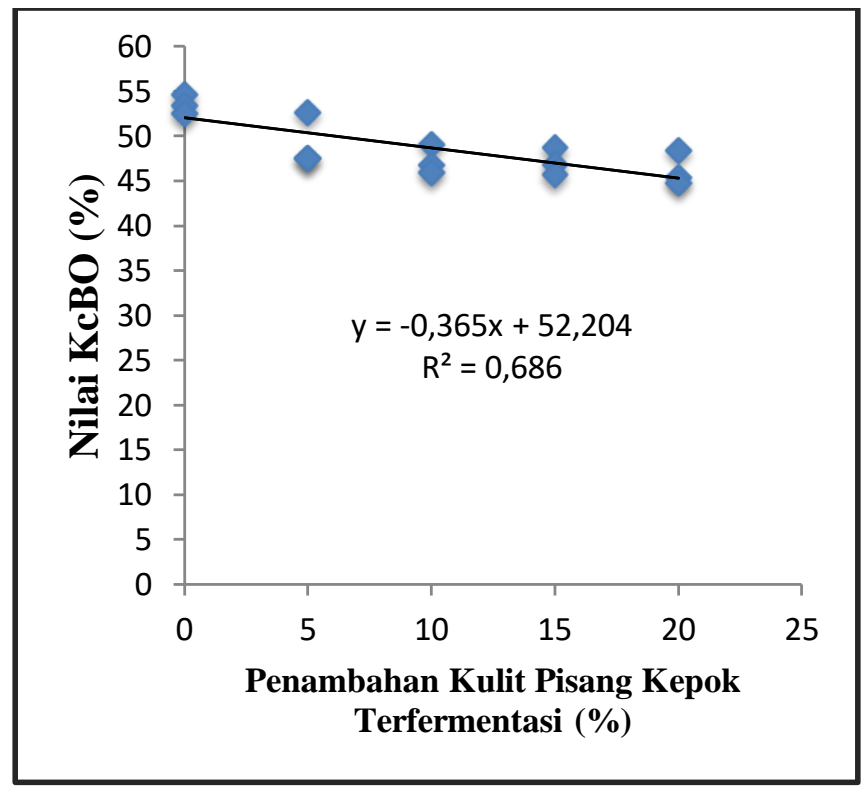

Gambar 1. Grafik Regresi Liniear KcBK

\section{Kecernaan Bahan Kering (KcBK)}

Berdasarkan hasil analisis ragam pada Tabel 4. menunjukkan bahwa penambahan kulit pisang kepok terfermentasi dalam pakan lengkap berpengaruh sangat nyata $(\mathrm{P}<0,01)$ terhadap nilai kecernaan bahan kering. Penurunan nilai kecernaan bahan kering pakan lengkap tiap perlakuan masing-masing sebesar 4,21\% (P1); 6,26\% (P2); 6,42\% (P3); dan 7,36\% (P4). Pada grafik regresi linear nilai $\mathrm{KcBK}$ (Gambar 1) memiliki nilai $\mathrm{R}^{2}$ sebesar $68,6 \%$, hal tersebut menandakan bahwa pengaruh pemberian kulit pisang kepok terfermentasi dalam pakan komplit berpengaruh 68,6\% terhadap nilai $\mathrm{KcBK}$.

Setiap kenaikan penambahan kulit pisang kepok terfermentasi sebesar $1 \%$ dalam pakan lengkap menyebabkan penurunan nilai kecernaan bahan kering
(KcBK) sebesar 0,365. Menurut pendapat Suprapto, Suhartati, dan Widiyastuti (2013) bahwa protein pakan berperan terhadap pertumbuhan mikroba dalam rumen. Semakin banyak protein yang dimanfaatkan oleh mikroba rumen maka pertumbuhan mikroba menjadi optimum. Seiring meningkatknya populasi rumen akan meningkatkan aktivitas mikroba rumen yang akan memproduksi enzim selulolitik yang lebih tinggi sehingga mikroba akan lebih mudah dan cepat untuk mencerna serat kasar. Serat kasar merupakan salah satu faktor yang berpengaruh terhadap nilai kecernaan bahan kering suatu bahan pakan dikarenakan lamanya degradasi serat kasar oleh mikroba rumen.

Menurut pendapat Nawaz and Ali (2016) bahwa lemak memiliki beberapa manfaat salah satunya adalah menaikkan 
densitas energi dalam pakan. Lemak terabsorbsi dalam partikuler rumen memproteksi serat kasar terhadap fermentasi dalam rumen serta bersifat toksik terhadap mikroba selulotik sehingga menurunkan daya cerna pakan. Hal ini senada dengan pendapat Harvantine and Allen (2005) bahwa lemak tidak jenuh majemuk berdampak negatif terhadap mikroba rumen tertentu dikarenakan bersifat toksik dan berdampak terhadap populasi mikroba rumen. Populasi mikroba rumen berpengaruh terhadap aktivitas untuk mendegradasi nutrisi dalam pakan.

\section{Kecernaan Bahan Organik (KcBO)}

Berdasarkan hasil analisis ragam pada Tabel 4. menunjukkan bahwa pemberian kulit pisang kepok terfermentasi dalam pakan lengkap berpengaruh sangat nyata $(\mathrm{P}<0,01)$ terhadap kecernaan bahan organik. Penurunan nilai $\mathrm{KcBO}$ tiap perlakuan masing-masing sebesar 2,03\% (P1); 4,33\% (P2); 4,86\% (P3); dan 6,85\% (P4). Adanya penurunan terhadap nilai $\mathrm{KcBK}$ berkorelasi positif pada nilai KcBO yang menunjukkan penurunan pada tiap perlakuan.

Nilai kecernaan bahan organik lebih tinggi dibandingkan nilai kecernaan bahan kering disebabkan dalam kecernaan bahan kering masih mengandung abu dan pada kecernaan bahan organik sudah tidak mengandung abu. Abu dalam bahan kering berdampak terhadap lambatnya daya cerna bahan kering pakan, sehingga bahan organik tanpa kandungan abu lebih mudah dicerna oleh mikroba rumen. Penurunan kecernaaan bahan organik diduga karena kemampuan mikroba rumen dalam menerima nutrisi telah melebihi batas maksimal sehingga mikroba rumen tidak mampu memanfaatkan berdampak pada penurunan aktivitas mikroba rumen (Dewi, Mukodiningsih, dan Sutrisno, 2012).

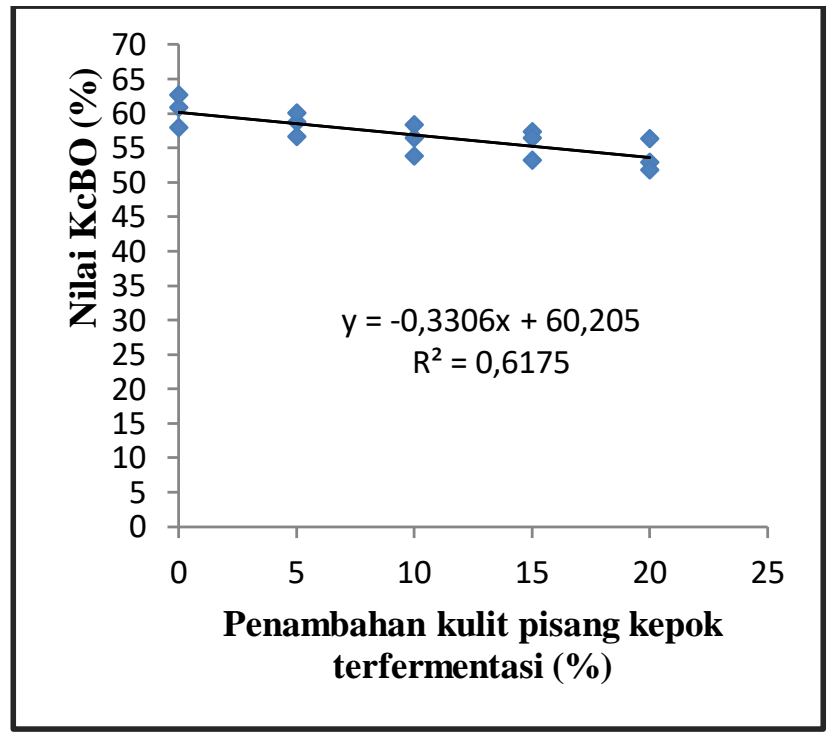

Gambar 2. Grafik Regresi Liniear KcBO

Pada grafik regresi linear nilai $\mathrm{KcBO}$ (Gambar 2) memiliki nilai $\mathrm{R}^{2}$ sebesar $61,8 \%$, hal tersebut menandakan bahwa pengaruh penambahan kulit pisang kepok terfermentasi dalam pakan komplit berpengaruh $61,8 \%$ terhadap nilai $\mathrm{KcBO}$. Setiap kenaikan penambahan kulit pisang kepok terfermentasi sebesar $1 \%$ dalam pakan lengkap menyebabkan penurunan nilai kecernaan bahan organik (KcBO) sebesar 0,311. Menurut penelitian Pramudiyawati dan Muhtarudin (2006) bahwa kandungan protein kasar berpengaruh terhadap nilai $\mathrm{KcBO}$. Kandungan protein kasar suatu bahan pakan sangat berpengaruh terhadap kecernaan baik secara jumlah maupun komposisi kimia. Seiring meningkatnya kandungan protein kasar dalam pakan menyebabkan kenaikan kecernaan bahan organik berkisar 15,50- 
$51,77 \%$. Protein kasar mengalami hidrolisis menjadi peptida oleh enzim yang dihasilkan mikroba rumen dan diubah menjadi asam amino. Asam amino sebagian dirombak menjadi amonia $\left(\mathrm{NH}_{3}\right)$ dalam proses amoniasi dan digunakan oleh mikroba rumen sebagai penyusun protein tubuh sehingga banyak bahan organik dapat terdegradasi.

Lemak kasar juga berperan dalam menurunkan kecernaan bahan organik pakan lengkap. Seiring dengan meningkatnya kandungan lemak kasar kecernaan bahan organik mengalami penurunan. Hal ini sesuai dengan pendapat Priyanto, dkk. (2017) bahwa penggunaan minyak jagung sebesar 2 dan $4 \%$ dalam konsentrat dan ditambahkan kedalam pakan lengkap menurunkan kecernaan bahan organik.

\section{KESIMPULAN}

1. Penambahan kulit pisang kepok (Musa paradisiaca L.) terfermentasi sampai $20 \%$ menurunkan kandungan BK, BO, PK, SK, dan Abu tetapi meningkatkan kandungan LK pada pakan lengkap.

2. Semakin besar penambahan kulit pisang kepok (Musa paradisiaca L.) terfermentasi dalam pakan lengkap menurunkan kecernaan bahan kering dan kecernaan bahan organik. Penggunan kulit pisang kepok terfermentasi dalam pakan lengkap optimum pada penambahan $5 \%$.

\section{UCAPAN TERIMA KASIH}

Penulis mengucapkan terima kasih kepada Dr. Ir. Herni Sudarwati, MS. dan Dr. Ir. Mashudi, M.Agr,Sc. yang telah membimbing selama penelitian ini, serta beberapa pihak yang telah membantu selama penelitian.

\section{DAFTAR PUSTAKA}

Agustono, A., Herviana, W., \& Nurhajati, T. (2011). Kandungan protein kasar dan serat kasar kulit pisang kepok (musa paradisiaca) yang difermentasi dengan trichoderma viride sebagai bahan pakan alternatif pada formulasi pakan ikan mas (cyprinus carpio). Jurnal Kelautan: Indonesian Journal of Marine Science and Technology, 4(1), 53-59. https://doi.org/10.21107/jk.v4i1.890

Anonimus. (2011). Badan Pusat Statistik Indonesia Produksi Buah Tanaman Pisang Tahun 2016.

Astuti, T. (2016). Digestibility of Ration Base on Banana Peel Bioprocessed with Local Microorganism. Bengkulu: International Seminar on Promoting Local Resources for Food and Health.

Astuti, T., Sari, Y., \& Zulkarnain. (2013). Pengaruh Fermentasi kulit pisang dengan mikroorganisme lokal (mol) pada lama pemeraman dan sumber MOL yang berbeda terhadap kandungan fraksi serat sebagai pakan ternak. Jurnal Ipteks Terapan, 7(3), 19-25.

Dewi, N. K., Mukodiningsih, S., \& Sutrisno, C. I. (2012). Pengaruh fermentasi kombinasi jerami padi dan jerami jagung dengan aras isi rumen kerbau terhadap kecernaan bahan kering dan bahan organik secara in vitro. Animal Agriculture Journal, 1(2), 134-140.

Fariani, A., Astuti, W., Muslim, G., \& Abrar, A. (2014). Kualitas Kecernaan Complete Feed Block (CFB) Berbasis Limbah Industri Gula Sebagai Pakan Ternak Ruminansia Secara In Vitro. Palembang: Prosiding Seminar Nasional Lahan Suboptimal. 
Fitriani, F., \& Asyari, H. (2017). Kandungan protein kasar dan serat kasar pakan komplit berbasis tongkol jagung dengan penambahan azolla sebagai pakan ruminansia. Jurnal Galung Tropika, 6(1), 12-18. https://doi.org/10.31850/JGT.V6I1.181

Harvatine, K., \& Allen, M. (2005). The effect of production level on feed intake, milk yield, and endocrine responses to two fatty acid supplements in lactating cows. Journal of Dairy Science, 88(11), 40184027. https://doi.org/10.3168/jds.S0022-0302(05)73088-5

Has, H., Indi, A., \& Pagala, A. (2017). Karakteristik Nutrien Kulit Pisang Sebagai Pakan Ayam Kampung Dengan Perlakuan Pengolahan Pakan Yang Berbeda. Kendari: Seminar Nasional Riset Kuantitatif Terapan.

Koni, T. (2013). Pemanfaatan limbah kulit pisang lilin (musa paradisiaca) sebagai pakan alternatif ayam pedaging (gallus galus domesticus). JITV, 18(2), 153-157. https://doi.org/10.14710/jil.14.1.11-17

Manorek, J. M., Wolayan, F. R., Untu, I. M., \& Liwe, H. (2017). Biokonversi kulit pisang raja (musa paradisiaca) dengan rhizopus oligosphorus terhadap perubahan kandungan abu, serat kasar dan lemak kasar. ZOOTEC, 38(1), 66-76.

Mookolang, M. C., Wolayan, F. R., Imbar, M. R., \& Toar, W. L. (2018). Bionkonversi kulit pisang raja (musa paradisiaca) dengan rhizopus oligosporus terhadap perubahan kandungan bahan kering, bahan organik dan protein kasar. ZOOTEC, $38(1), 56-65$.

Nuraini, N., Mahata, M. E., \& Djulardi, A. (2016). Peningkatan kualitas campuran kulit pisang dengan ampas tahu melalui fermentasi dengan phanerochaete chrysosporium dan neurospora crassa sebagai pakan ternak. Jurnal Peternakan, 11(1), 22-28. https://doi.org/10.24014/JUPET.V11I1.2324

Paiva, P. G., Valle, T. A. Del, Jesus, E. F., Bettero, V. P., Almeida, G. F., Bueno, I. C. S., Rennó, F. P. (2016). Effects of crude glycerin on milk composition, nutrient digestibility and ruminal fermentation of dairy cows fed corn silage-based diets. Animal Feed Science and Technology, 212, 136-142. https://doi.org/10.1016/J.ANIFEEDSCI.2015.12.016

Permana, H., Chuzaemi, S., Marjuki, \& Mariyono. (2014). Pengaruh Pakan Dengan Level Serat Kasar Berbeda Terhadap Konsumsi, Kecernaan dan Karakteristik VFA Pada Sapi Peranakan Ongole. Malang: Fakultas Peternakan Universitas Brawijaya.

Prayuwidayati, M., \& Muhtarudin, M. (2006). Pengaruh berbagai proporsi dedak gandum dalam fermentasi terhadap kadar protein dan kecernaan secara in vitro. Jurnal Indonesia Tropical Animal Agriculture, 31(3), 147-151.

Priyanto, A., Endraswati, A., Febriyani, N. C., Nopiansyah, T., \& Nuswantara, L. K. (2017). Pengaruh pemberian minyak jagung dan suplementasi urea pada ransum terhadap profil cairan rumen $(\mathrm{KcBK}, \mathrm{KcBO}, \mathrm{pH}, \mathrm{N}-\mathrm{NH} 3$ dan Total Mikroba Rumen) (the effect of corn oil and urea supplementation on rations to the rumen liquid $(\mathrm{KcBK}$, $\mathrm{KcBO}, \mathrm{pH}, \mathrm{n}-\mathrm{NH} 3$ and Total Microbial Rumen)). Jurnal Ilmu Ternak, 17(1), 1-9. https://doi.org/10.24198/JIT.V17I1.14794

Styawati, N. E., Muhtarudin, \& Liman. (2014). Pengaruh lama fermentasi trametes sp. terhadap kadar bahan kering, kadar abu, dan kadar serat kasar daun nenas varietas smooth cayene. Jurnal Ilmiah Peternakan Terpadu, 2(1), 19-24. https://doi.org/10.23960/JIPT.V2I1.P\%P 
Suprapto, H., Suhartati, F. M., \& Widyastuti, T. (2013). Kecernaan serat kasar dan lemak kasar complete feed limbah rami dengan sumber berbeda pada kambing peranakan etawa lepas sapih. Jurnal Ilmiah Peternakan, 1(3), 936-946.

Suprayogi, W. P. S. (2010). Inkorporasi sulfur dalam protein onggok melalui teknologi fermentasi menggunakan saccaromyces cerevisae. Caraka Tani, 25(1), 33-37.
Wina, E., \& Susana, W. R. (2013). Manfaat lemak terproteksi untuk meningkatkan produksi dan reproduksi ternak ruminansia. Wartazoa, 23(4), 177184.

Wulandari, S., Fathul, F., \& Liman. (2015). Pengaruh berbagai komposisi limbah pertanian terhadap kadar air, abu dan serat kasar pada wafer. Jurnal Ilmiah Peternakan Terpadu, 3(3), 104-109. 